\title{
Ontogeny of islet cell antibodies, insulin autoantibodies and insulitis in the non-obese diabetic mouse
}

\author{
S. Reddy, N.J. Bibby and R. B. Elliott \\ Department of Paediatrics, School of Medicine, University of Auckland, Auckland, New Zealand
}

Summary. The predictive value of insulitis, islet cell cytoplasmic antibodies and insulin autoantibodies for insulin-dependent diabetes was studied in young female non-obese diabetic mice. The ontogeny of the three markers was examined cross-sectionally at days $15,25,40$ and 90 while islet cell antibodies and insulin autoantibodies were studied longitudinally from day 35 or day 144-168 until approximately day 250. Insulitis was first observed at day $40(50 \%)$ and subsequently at day $90(70 \%)$. Islet cell antibodies and insulin autoantibodies were present at day 15 in $46 \%$ and $54 \%$ of the animals respectively. The rate of islet cell antibodies was slightly higher at day $25(60 \%)$ than at day $40(40 \%)$ and day $90(54 \%)$ whereas antibodies to insulin were present in all samples from day 25-90. At day 40 and day 90 insulitis and insulin autoantibodies were present together in $42 \%$ and $70 \%$ of the animals, respectively, while insulitis and islet cell antibodies had a lower rate of concordance $(17 \%$ and $42 \%$, respectively; diabetes rate, $30 \%$ ). The concordance rates for islet cell antibodies and insulin autoantibodies were $42 \%$ at day 40 and $54 \%$ at day 90 . Concordance for all three markers was first observed at day $40(17 \%)$ which increased to $38 \%$ at day 90 . In longitudinal studies, islet cell antibodies and insulin autoantibodies were often present together whether or not diabetes supervened. In the islet cell antibody procedure, immunoreactive cells were shown immunohistochemically to correspond with insulin and/or glucagon cells. However, this staining was not suppressible with insulin- or glucagon- absorbed sera, implying the presence of non-hormonal autoantigens. We conclude that the three markers investigated are expressed early after birth and well before clinical symptoms appear in this animal model. Both islet cell antibodies and insulin autoantibodies preceded insulitis but the prevalence rate for each marker or their degree of concordance was different from the anticipated rate of diabetes in our colony. Consequently, the early expression of the three markers alone is not predictive of diabetes although concordance for the two, or all three markers may be of some value. However, no animal developed diabetes without the prior appearance of both islet cell antibodies and insulin autoantibodies.

Key words: NOD mice, insulitis, islet cell antibodies, insulin autoantibodies, ontogeny, immunofluorescence.
The non-obese diabetic (NOD) mouse develops insulin-dependent diabetes spontaneously from approximately 120 days onward. The rate of diabetes depends on the particular colony but is always considerably higher in females than in males [1]. The histopathology of the pancreas includes insulitis and B-cell loss relatively early after weaning $[1,2]$. The severity of insulitis shows good correlation with the degree of impairment of first phase insulin release in response to glucose perfusion in vitro [3]. Humoral antibody changes, such as the presence of islet cell cytoplasmic antibodies (ICA) and islet cell surface antibodies (ICSA) have also been detected in the sera of prediabetic NOD mice $[4,5]$. In humans with Type 1 (insulin-dependent) diabetes it is known that such antibodies (ICA and ICSA) are usually present well before diagnosis and several recent studies have now shown that antibodies directed against endogenous insulin (insulin autoantibodies (IAA)) also precede the disease [6]. In light of these findings, we were interested in studying possible markers of diabetes proneness (insulitis, ICA and IAA) cross-sectionally and longitudinally in the NOD mouse to establish their timing of onset and assess their predictive value.

\section{Materials and methods}

NOD mice from an in-house strain held by the University of Ehime City, Japan, have a rate of $30 \%$ diabetes in females between the ages of 120 and 200 days. This was confirmed in 41 females from this strain housed and fed in New Zealand (13/41 diabetic between 119 and 241 days old). Diabetes was defined as the presence of persistent glycosuria over $3-4$ days (Testape $3+$ ). 
NOD female mice were studied at day $15(n=13), 25(n=8), 40$ $(n=12)$ and $90(n=13)$. None showed glycosuria at any stage. Animals were bled, killed and the pancreas removed and fixed in Bouin's fluid for $2 \mathrm{~h}$. After embedding in paraffin, sections ( $3 \mu \mathrm{m})$ were stained with haematoxylin and eosin and examined for the presence of lymphocytic infiltrates within the islet or in peri-insular areas. Lymphocytic cells within ducts or blood vessels close to the islet were not included.

Blood was also sampled at fortnightly intervals from NOD mice from either day $35(n=5)$ or from day 144-168 ( $n=9)$ until the diagnosis of diabetes, or continued until approximately 250 days of age in non-diabetic animals. Pancreata were removed and stained as above.

All sera were stored at $-20^{\circ} \mathrm{C}$ until analysis. Islet cell cytoplasmic antibodics (ICA) were detected by a previously reported indirect immunofluorescence procedure with minor modifications [4]. As substrate for ICA staining, normal pancreata obtained from 45-90 day outbred albino Swiss mice (Animal Resources Centre, Perth, Australia) were fixed in Bouin's fluid, processed and sectioned as described above. Sera from NOD and normal mice after diluting 1:1 with phosphate-buffered saline (PBS) were applied to $3 \mu \mathrm{m}$ sections and incubated at $37^{\circ} \mathrm{C}$ for $1 \mathrm{~h}$. After washing in PBS for $20 \mathrm{~min}$, sections were incubated with goat anti-mouse immunoglobin (Ig) coupled to fluorescein isothiocyanate (FITC, South Pacific Immunological Laboratories (SPi), Palmerston North, New Zealand) at a dilution of $1: 10$ in PBS for $30 \mathrm{~min}$ at $37^{\circ} \mathrm{C}$. Sections were then washed for $20 \mathrm{~min}$, mounted with glycerol-PBS and viewed with a Nikon fluorescence microscope. Test sera with a fluorescence intensity of pancreatic islet cells greater than control sera were assigned positive. All positive sera were re-tested in the procedure described, before and after neutralisation with either rat and bovine insulin or porcine glucagon (Novo, Bagsvaerd, Denmark; $1 \mu \mathrm{g}$ hormone per $\mu \mathrm{l}$ neat serum, $18 \mathrm{~h}$ at $4^{\circ} \mathrm{C}$ ). The identity of the islet cell types showing positive staining in the ICA procedure was studied immunohistochemically by staining serial normal mouse pancreatic sections with NOD mouse serum $(1: 1)$ and with either guinea pig anti-insulin serum $(1: 80)$ or rabbit antiserum to glucagon $(1: 80)$, bovine pancreatic polypeptide $(1: 80)$ or somatostatin $(1: 40)$ as described previously [7]. The immunofluorescence was observed after incubating sections with the appropriate FITC-second antibody (goat anti-mouse Ig, SPi, sheep anti-guinea pig or anti-rabbit gamma globulin, Wellcome, Beckenham, GB).

In addition, sections were stained simultaneously with a mixture of NOD mouse serum and one of the hormone antisera. The resulting immunoreaction was studied by adding two of the corresponding fluorochrome-labelled second antibody to each section (goat antimousc Ig-FITC, SPi, goat anti-mouse Ig-rhodamine, Tago, Burlingame, Calif, USA, swine anti-rabbit gamma globulin-rhodamine-Dako, Glostrup, DK, sheep anti-rabbit or anti-guinea pig gamma globulin-FITC, Wellcome) at a dilution of $1: 20$.

Insulin autoantibodies in NOD mouse sera were determined by minor modifications of previously reported procedures $[8,9]$ in 96-well, flat-bottom micro-titre plates (Nunc, Kamstrup, DK). Wells were coated with $5 \mu \mathrm{g}$ porcine insulin (Novo) in $100 \mu \mathrm{l}$ PBS for 3 days at $4^{\circ} \mathrm{C}$ and then either used immediately or stored at $-20^{\circ} \mathrm{C}$. Prior to assay insulin-coated plates were washed $(3 \times$ with washing buffer: $0.05 \%$ v/v Tween, Sigma, St. Louis, Missouri, USA, in PBS) and blocked with $2 \% \mathrm{w} / \mathrm{v}$ gelatin (Biorad Laboratories, Richmond, (alif, USA) in PBS for $2 \mathrm{~h}$ at room temperature. After washing, wells were incubated with $50 \mu \mathrm{l}$ of NOD mouse sera $(1: 50)$ or normal mouse sera $(1: 50)$ for $2.5 \mathrm{~h}$ at room temperature. The diluent for serum and in the subsequent step was $0.1 \% \mathrm{w} / \mathrm{v}$ BSA in PBS. Plates were washed and then $50 \mu \mathrm{l}$ of goat anti-mouse IgG-peroxidase (heavy and light chains, 1:250, SPi or 1:8000 Vector Laboratories, Burlingame) was added to all wells and incubated for $1 \mathrm{~h}$. After further washing $100 \mu \mathrm{l}$ of substrate consisting of $2.2 \mathrm{mmol} / \mathrm{l} 0$-phenylene-diamine (Sigma) and $0.012 \% \mathrm{v} / \mathrm{v} \mathrm{H}_{2} \mathrm{O}_{2}$ in $0.05 \mathrm{~mol} / 1$ citric acid and $0.1 \mathrm{~mol} / 1$ phosphate buffer, $\mathrm{pH} 5$ was added to each well. After $10-20 \mathrm{~min}$ at room temperature the reaction was stopped by addition of $50 \mu 10 \% \mathrm{v} / \mathrm{v} \mathrm{HCl}$ and the optical density at $486 \mathrm{~nm}$ was read in an ELISA plate reader. In cross-sectional studies IAA values for test sera were expressed after subtraction of mean optical densities of age-matched normal sera ( 5 normal sera per age group) while in longitudinal studies they were expressed after subtracting the mean values for normal sera of day 40-90 mice ( 3 samples). Test sera were considered positive if this difference exceeded 2 standard deviations of the means for normal sera.

\section{Statistical analysis}

The difference between the rates of the three markers examined in cross-sectional studies were tested using Fisher's exact test while the Student's t-test was used for the IAA values.

\section{Results}

The pattern of ICA staining in sections of normal mouse pancreas by sera from NOD or normal mouse is shown in Figure $1 \mathrm{a}$ and $\mathrm{b}$. Of the 141 serum samples tested in the ICA procedure, 81 showed staining of the majority of islet cells while 15 sera stained cells which were predominantly located in the periphery of the islets (Fig. $1 \mathrm{a}, 2 \mathrm{a}, 3 \mathrm{a}$ ). In Figures $1 \mathrm{c}$ and $\mathrm{d}$ and $2 \mathrm{~b}$ and $\mathrm{c}$ adjacent sections have been stained by the indirect immunofluorescence procedure for either insulin or glucagon. Sera showing specific peripheral staining when applied simultaneously with either antiserum to glucagon, somatostatin or pancreatic polypeptide hormone in the immunofluorescence procedure revealed that most of the ICA immunoreactive cells corresponded to glucagon cells (Fig. $3 \mathrm{a}$ and b).

Normal pancreatic islets still showed staining when ICA positive sera were re-stained following pre-absorption with insulin or glucagon.

The presence of lymphocytic infiltrations within and in close apposition to pancreatic islets of NOD mice of various ages studied cross-sectionally and the corresponding ICA and IAA results are shown in Table 1. Insulitis was absent in all mice at day 15 and day 25 but was present from day $40(50 \%)$ and was significantly higher at day 90 than at day $15(p=0.05)$. Islet cell antibodies showing weak staining were present in $6 / 13$ mice at day 15 . At day 25 , the ICA rate had increased to almost $60 \%$. Concordance for both markers was seen in 2 mice at day $40(17 \%)$ and 6 mice at day $90(46 \%)$. In contrast, the presence of IAA was seen in $54 \%$ of mice studied at day 15 and in all mice at the subsequent ages. However, the mean values for IAA were significantly higher at day $25(0.38 \pm 0.08), 40$ $(0.27 \pm 0.16)$ and $90(0.38 \pm 0.10)$ than at day 15 $(0.10 \pm 0.04, p=0.05)$. Concordance rates for IAA and insulitis were $42 \%$ at day 40 and $69 \%$ at day 90 whereas for ICA and IAA this rate was relatively low at day $15(15 \%)$ but considerably higher at day 25-90 (almost $50 \%$ ). Animals concordant for all three markers were first observed at day $40(17 \%)$ which increased to $38 \%$ at day 90 .

The presence of ICA studied longitudinally and the 

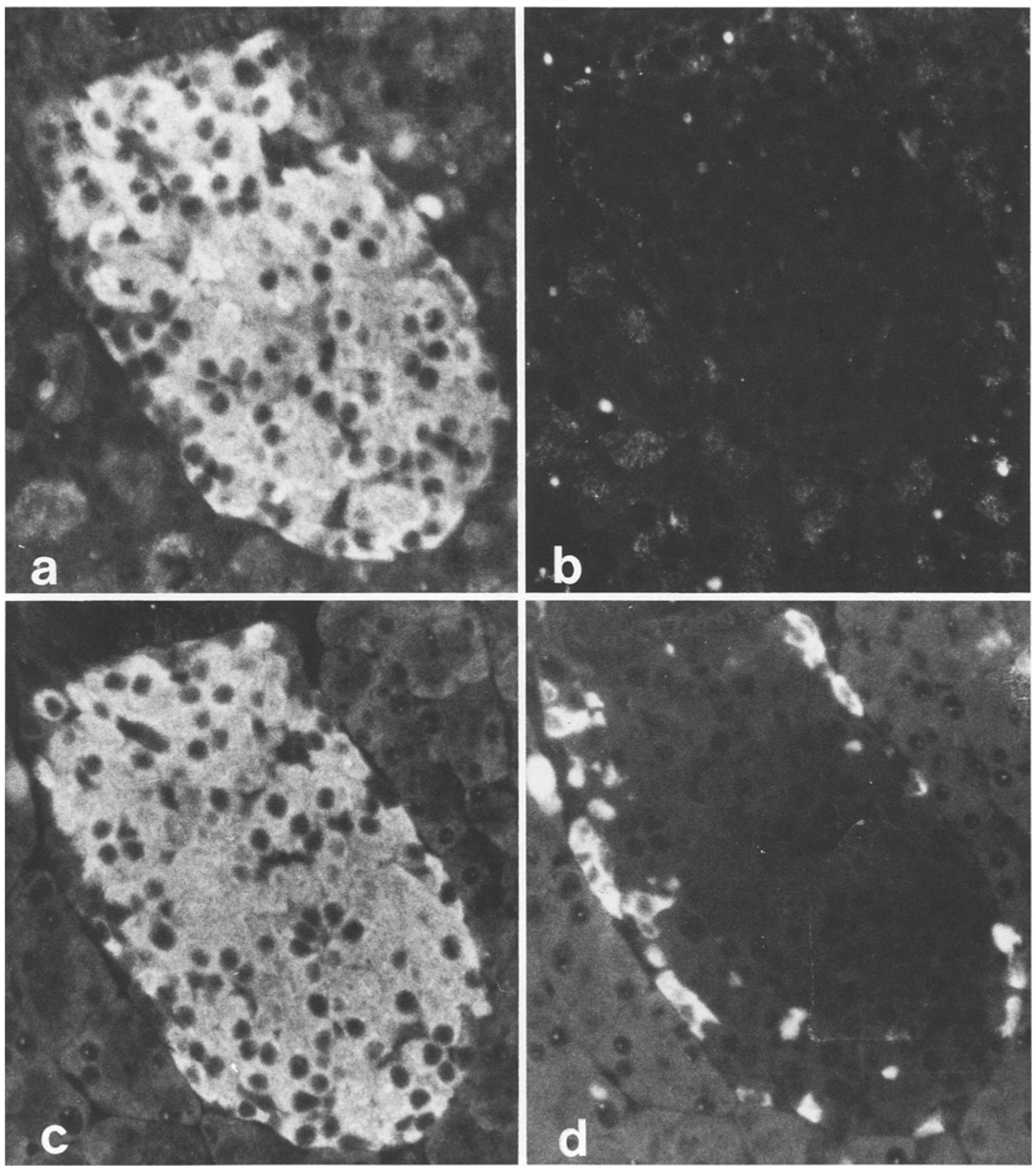

Fig. 1. Photomicrographs of normal mouse pancreatic sections stained by ICA procedure or by indirect immunofluorescence for insulin or glucagon. a Serum from NOD mouse reacted by the ICA procedure; note staining of almost all islet cells. b Serum from normal mouse reacted by the ICA procedure; note absence of staining of islet cells. c and d a single section adjacent to (a) stained by indirect immunofluorescence for insulin (c) and glucagon (d). $\times 550$

corresponding IAA values (for 7 mice) are shown in Table 2. Four out of the 5 mice studied from day 35 (mice 1-4) developed diabetes at the ages indicated. In this group ICA were detected in 4 mice by day 53 and by day 97 in the remaining mouse (mouse 1). Most of the ICA-positive sera from mice 2-5 also had varying levels of IAA whether or not diabetes supervened. The earliness of appearance of either ICA or IAA did not predict the time of onset of diabetes.
Table 2 also includes ICA results for mice studied from day 144-220 (mice 6-9) and day 168-245 (mice 10-14). The corresponding serum values for IAA from mice 7,8 and 9 are also shown. Islet cell antibodies were detected in all 9 mice but only 4 developed diabetes. Most ICA-positive sera were also positive for IAA. However, 1 mouse which initially showed ICA and IAA (mouse 8) became negative for both antibodies shortly before developing diabetes at 192 days of age. 

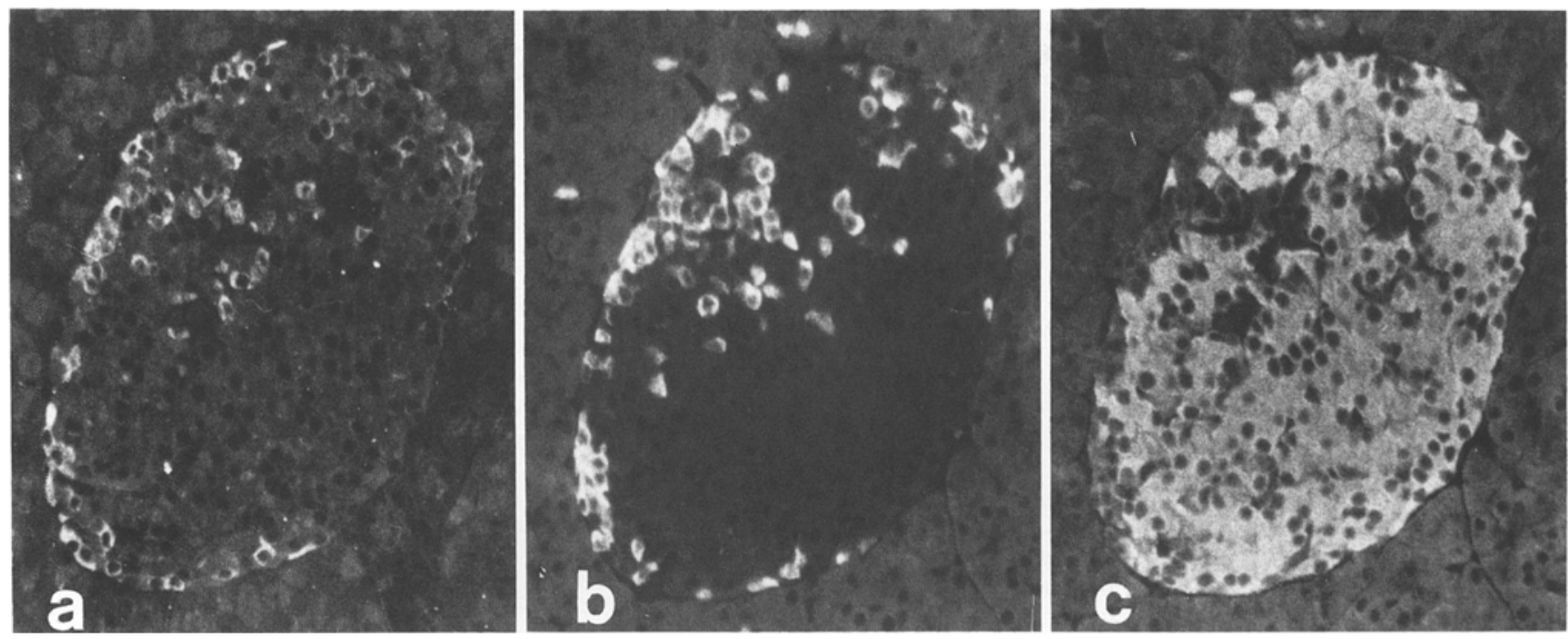

Fig. 2. Photomicrographs of normal mouse pancreatic sections stained by ICA procedure or by indirect immunofluorescence for insulin or glucagon. a Serum from NOD mouse reacted by the ICA procedure showing staining of some islet cells located either in the periphery or scattered more centrally. $\mathbf{b}$ and $\mathbf{c}$ a single section adjacent to (a) stained by indirect immunofluorescence for glucagon (b) and insulin (c). $\times 250$
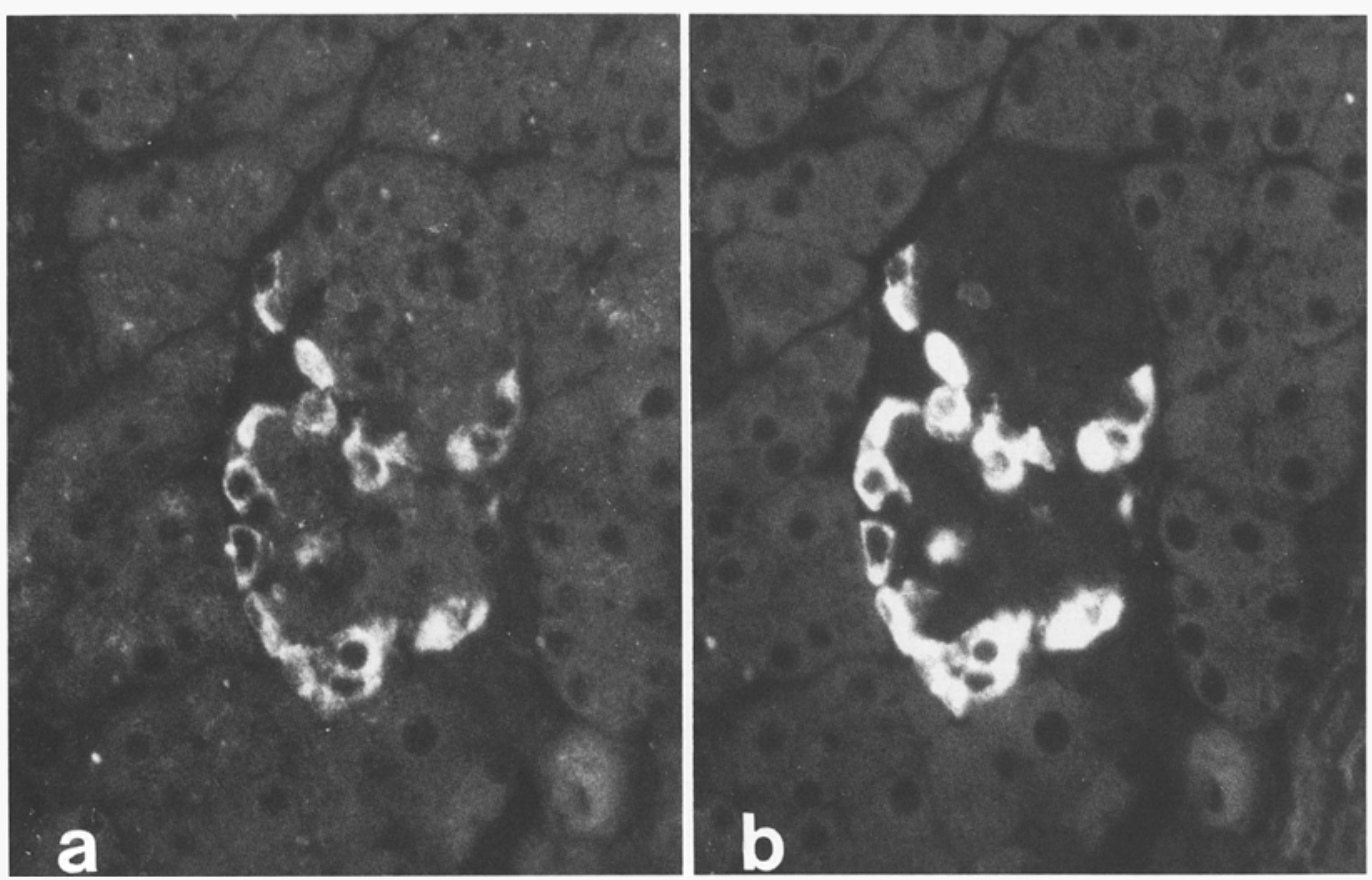

Fig. 3. A normal mouse pancreatic section stained simultaneously with serum from NOD mouse by ICA (a) and with rabbit anti-glucagon serum by indirect immunofluorescence $(b)$. Note staining of identical cells by both procedures. $\times 550$

\section{Discussion}

There are now several studies which suggest that insulin-dependent diabetes is preceded at least in part by disturbances in the immune system. In humans at risk and in the NOD mouse and the BB rat this phenomenon is characterised by the presence of islet cell and insulin autoantibodies, lymphocytic infiltrations and Tcell aberrations [10-14].

The present cross-sectional and longitudinal studies were undertaken in the NOD mouse to see if the rates of three likely markers of diabetes (insulitis, ICA and IAA), their ontogenic expression and/or degree of concordance could confer predisposition to insulin-dependent diabetes. We have shown that all three markers appear relatively early after birth and well before clinical diabetes. Serum ICA and IAA were first detected at day 15 and preceded insulitis which appeared at day 40 . However, the rates for the three markers in our cross-sectional studies were much higher than the expected $30 \%$ rate for diabetes in the present colony. These results suggest that the presence of 
Table 1. Ontogenic relationship of ICA, IAA and insulitis in female NOD mice studied cross-sectionally from day 15-90

\begin{tabular}{lllllllll}
\hline $\begin{array}{l}\text { Age } \\
\text { (days) }\end{array}$ & $\begin{array}{l}\text { Number of } \\
\text { animals }\end{array}$ & $\begin{array}{l}\text { Number } \\
\text { with insulitis }\end{array}$ & $\begin{array}{l}\text { Number } \\
\text { with ICA }\end{array}$ & $\begin{array}{l}\text { Number } \\
\text { with IAA }\end{array}$ & $\begin{array}{l}\text { Number with } \\
\text { insulitis } \\
\text { and ICA }\end{array}$ & $\begin{array}{l}\text { Number with } \\
\text { insulitis } \\
\text { and IAA }\end{array}$ & $\begin{array}{l}\text { Number with } \\
\text { ICA and IAA }\end{array}$ & $\begin{array}{l}\text { Number with } \\
\text { insulitis } \\
\text { ICA and IAA }\end{array}$ \\
\hline 15 & 13 & 0 & 6 & 7 & 0 & 0 & 0 \\
25 & 8 & 0 & 5 & 8 & 0 & 0 & 5 & 2 \\
40 & 12 & 6 & 5 & 12 & 2 & 5 & 5 & 7 \\
90 & 13 & 9 & 7 & 13 & 6 & 9 & 5 \\
\hline
\end{tabular}

In the IAA assay, the mean optical densities $\pm S D$ for age-matched normal sera ( 5 sera per age group) were: day $15=0.442 \pm 0.035$; day $25=0.441 \pm 0.035$; day $40=0.275 \pm 0.046$; day $90=0.285 \pm 0.065$. All NOD mouse sera were assayed in duplicate and assigned 'positive' if their mean optical densities were greater than the corresponding mean optical densities of age-matched normal sera by at least 2 SD

Table 2. Presence (+) or absence (-) of ICA in NOI) mouse sera sampled longitudinally from day 35-236 (mice 1-5), day 144-220 (mice 6-9) and day 168-245 (mice 10-14). The corresponding serum IAA values are indicated in brackets for mice 2-9 and have been expressed after subtraction of optical densities of test sera from the mean values for normal sera

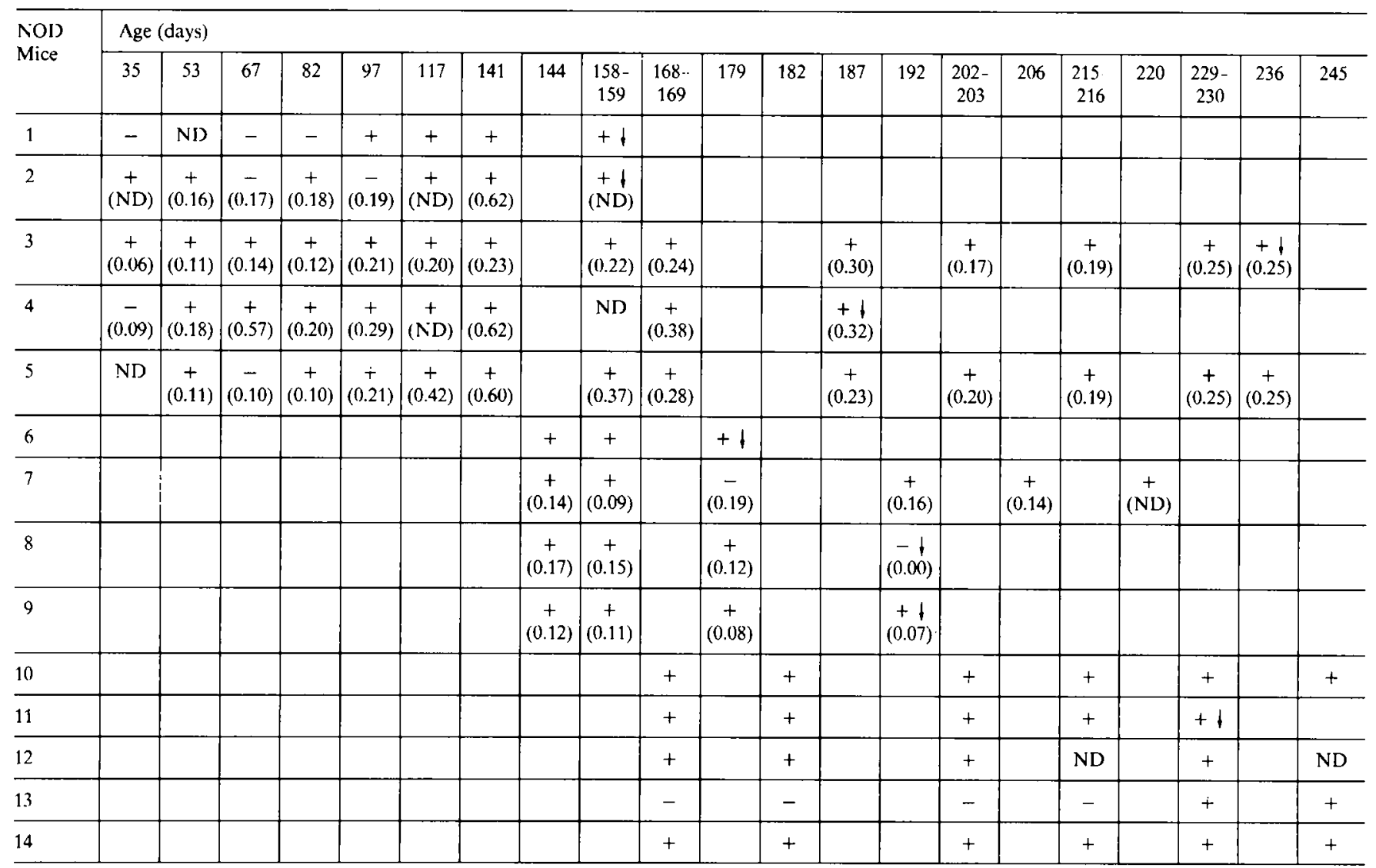

ND: Not determined; $\downarrow$ : Age at onset of diabetes; All animals were females except mouse 5

either marker on its own cannot be used as a predictor of diabetes, although it is possible that concordance for the two or the three markers may be of some predictive value. Studies in the NOD mouse by others indicate that ICSA also precede the onset of diabetes but may be present in both diabetic and non-diabetic groups perhaps with diminished levels around the time of clinical onset [5].

Some of our ontogenic studies are similar to those in the BB rat where insulitis was observed after day 40 but serum ICSA appeared earlier, at day 28-30 [15]. The age of onset of insulitis in the NOD mouse report- ed by others is slightly different from our present observations. For example, Fujita et al. [2] observed insulitis at 4-5 weeks and Miyazaki et al. [13] at 3 weeks of age by light microscopy whereas Fujino-Kurihara et al. [16] observed these infiltrations at 2 weeks with the electron microscope. Likely reasons for these results may be due to differences in defining insulitis, ages of mice selected for cross-sectional studies and observation methods used. In our present study there was some evidence of much weaker ICA and IAA levels prior to weaning. Whether a change from a rodent milk diet to one consisting of foreign antigens is re- 
sponsible for enhancing the expression of these immune abnormalities is not known. Non-obese diabetic mice fed from weaning on nutritionally adequate diet not containing intact protein are protected against the development of diabetes [17]. It is interesting that ethnic groups who traditionally introduce cow's milk at an early stage have a high childhood diabetes rate, whereas those groups who suckle their infants for relatively long periods of time and do not use cow's milk as a weaning diet, have a very low rate. (R.B. Elliott, unpublished data). Alternatively, our observations may have been due to the passage of ICA-positive maternal immunoglobins in the newborn.

Sera from NOD mice examined longitudinally suggest that autoantibodies to insulin, like ICA, can be detected from an early age whether or not diabetes supervenes. Others have shown that in the high incidence $\mathrm{BB}$ rat a majority of the animals were also IAA positive from an early age, none of which were ICSA positive [18]. In the present study, although a formal proof for the presence of insulin autoantibodies by insulin inhibition was not performed, our test system, which utilised porcine insulin as the solid phase ligand would not have detected autoantibodies monospecific for mouse insulin. In our ICA procedure, the failure to suppress immunofluorescence after neutralisation of immune sera with insulin or glucagon, the staining of selective islet cell-types and the demonstration of IAA imply the presence of islet autoantigens of different chemical identities. In addition, autoantibodies with unique epitopes may be present. Further studies are in progress to define more precisely the autoantigenic determinants which show positive staining in our present ICA procedure and their immunochemical relationship to islet hormones. In the NOD mouse others have recently reported that monoclonal antibodies to islet cell surface antigens recognise two major polypeptides of molecular weights $64 \mathrm{~K}$ and $28 \mathrm{~K}$ [19]. The $64 \mathrm{~K}$ value has also been reported earlier by others using serum from Type 1 human diabetic patients and BB rats [15, 20]. In addition, a rabbit antiserum obtained after immunisation with dispersed rat islet cells could immunoprecipitate a $40 \mathrm{~K}$ glycoprotein [21]. Recently, others have also reported the presence of autoantigens of different biochemical properties $[22,23]$. These observations and our present results on the pattern of cellular staining in the ICA procedure, the presence of IAA in the NOD mouse and in humans before diabetes [14] suggest that it is unlikely that a single autoantigen is solely involved in the pathogenesis of insulin-dependent diabetes in this animal model.

Although the quantitation of IAA and ICA as predictors has not been addressed in this study, the present report does demonstrate the expression of ICA, IAA and insulitis relatively early after birth but at a rate higher than the anticipated rate for diabetes in our NOD mouse colony. These findings are in agreement with recent studies in the BB rat where potential markers of the disease such as an aberrant first phase insulin release, T-cell lymphopoenia and serum ICSA can be a feature of diabetic and non-diabetic animals [24-26]. Evidence for disease susceptibility can therefore be present in a larger group than previously thought but other factors may be necessary for clinical onset. The single mouse which at the time of development of diabetes was ICA and IAA negative, but was previously positive for both, is of interest if this animal model has parallels with the human disease.

Acknowledgements. We thank Ms. C. Coppersmith and Ms. H. Black for typing the manuscript and Ms. L. Logan for the illustrations. This study was financed by the National Children's Health Research Foundation of New Zealand. Dr. K. Kida, Ehime University, Japan kindly supplied the NOD breeding stock.

\section{References}

1. Makino S, Kunimoto K, Muraoka Y, Mizushima Y, Katagiri K, Tochino $Y$ (1980) Breeding of a non-obese, diabetic strain of mice. Exp Anim (Tokyo) 29:1-13

2. Fujita T, Yui R, Kusumoto Y, Serizawa $Y$, Makino S, Tochino $Y$ (1982) Lymphocytic insulitis in a non-obese diabetic (NOD) strain of mice: an immunohistochemical and electron microscope investigation. Biomed Res 3: $429-443$

3. Kano Y, Kanatsuna T, Nakamura N, Kitagawa Y, Mori H, Kajiyama S, Nakano K, Kondo M (1986) Defect of the first-phase insulin secretion to glucose stimulation in the perfused pancreas of the non-obese diabetic (NOD) mouse. Diabetes 35: 486 - 490

4. Toyota T, Kataoka S, Sato J, Fujiya H, Hayashida Y, Goto Y, Kumagai K (1982) Islet-cell antibody and immunologic aspects of NOD mice. In: Mimura G, Baba S, Goto Y, Kobberling J (eds) Clinico-genetic genesis of diabetes mellitus. Excerpta Med, pp $185-192$

5. Yokono K, Shii K, Hari J, Yaso S, Imamura Y, Fjiri K, Ishihara K, Fujii S, Kazumi T, Taniguchi H, Baba S (1984) Production of monoclonal antibodies to islet cell surface antigens using hybridization of spleen lymphocytes from non-obese diabctic mice. Diabetologia 26: 379--385

6. Palmer JP, Asplin C.M, Clemons P, Lyen K, Tatpati O, Raghu PK, Paquette TL (1983) Insulin antibodies in insulindependent diabetics before insulin treatment. Science 222: $1337-1339$

7. Reddy S, Bibby NJ, Fisher SL, Elliott RB (1986) Immunolocalization of insulin, glucagon, pancreatic polypeptide and somatostatin in the pancreatic islets of the possum, Trichosurus vulpecula. Gen Comp Endocrinol 64: 157-162

8. Nell LJ, Virta VJ, Thomas JW (1985) Application of a rapid enzyme-linked immunosorbent microassay (elisa) to study human anti-insulin antibody. Diabetes 34:60.66

9. Wilkin T, Nicholson S, Casey C (1985) A micro enzyme-linked immunosorbent assay for insulin antibodies in serum. J Immunol Methods 76: 185194

10. Nakhooda AF, Like AA, Chappel CI, Wei C-N, Marliss EB (1978) The spontaneously diabetic Wistar rat (the "BB" rat). Studies prior to and during development of the overt syndrome. Diabetologia 14: 199-207

11. Dyrberg T, Nakhooda AF, Baekkeskov S, Lernmark A, Poussier P. Marliss EB (1982) Islet cell surface antibodics and lymphocyte antibodies in the spontancously diabetic BB Wistar rat. Diabetes 31: 278-281

12. Seemayer TA, Tannenbaum GS, Goldman HY, Colle E (1982) Dynamic time course studies of the spontaneously diabetic BB Wistar rat IIl. Light microscopic and ultrastructural observations of pancreatic islets of Langerhans. Am J Pathol 106: 237-249 
13. Miyazaki A, Hanafusa T, Yamada K, Miyagawa J, Fujino-Kurihara H, Nakajima H, Nonaka K, Tarui S (1985) Predominance of $\mathrm{T}$ lymphocytes in pancreatic islets and spleen of pre-diabetic non-obese diabetic (NOD) mice: a longitudinal study. Clin Exp Immunol 60: 622-630

14. Dean BM, Becker F, McNally JM, Tarn AC, Schwartz G, Gale EAM, Bottazzo GF (1986) Insulin autoantibodies in the pre-diabetic period: correlation with islet cell antibodies and development of diabetes. Diabetologia 29: 339-342

15. Backkeskov S, Dyrberg T, Lernmark A (1984) Autoantibodies to a 64-kilodalton islet cell protein precede the onset of spontaneous diabetes in BB rats. Science 224: 1348-1350

16. Fujino-Kurihara H, Fujita $H$, Hakura $A$, Nonaka $K$, Tarui $S$ (1985) Morphological aspects on pancreatic islets of non-obese diabetic (NOD) mice. Virchows Arch 49: 107-120

17. Elliott RB, Reddy SN, Bibby NJ, Kida K (1988) Dietary prevention of diabetes in the non-obese diabetic mouse. Diabetologia $31: 62-64$

18. Wilkin TJ, Scott-Morgan L, Diaz J-L, Casey CR, Armitage M, Betts $P$ (1986) The relationship between insulin autoantibodies (IAA) and islet cell antibodies (ICA) as serological markers for Type $\mathrm{I}$ diabetes in man and the BB rat. Diabetes 35:87 $\mathrm{A}$

19. Hari J, Yokono K, Yonezawa K, Amano K, Yaso S, Shii K, Imamura Y, Baba S (1986) Immunochemical characterization of anti-islet cell surface monoclonal antibody from non-obese diabetic mice. Diabetes 35: 517-522

20. Baekkeskov S, Nielsen JH, Marner B, Bilde T, Ludvigsson J, Lernmark A (1982) Autoantibodies in newly diagnosed diabetic children immunoprecipitate human pancreatic islet cell proteins. Nature 298: 167-169
21. Baekkeskov S, Lernmark A (1984) A B-cell glycoprotein of $\mathrm{Mr} 40000$ is the major rat islet cell immunogen following xenogenic immunisation. Diabetologia 27: 70-73

22. Nayak RC, Omar MAK, Rabizadeh A, Srikanta S, Eisenbarth GS (1985) "Cytoplasmic" islet cell antibodies: evidence that the target antigen is a sialoglycoconjugate. Diabetes 34:617-619

23. Boehm BO, Rosak C, Sasse U, Kaul S, Schoffling K (1986) Western-blot analysis of islet cell antibodies in Type 1 (insulindependent) diabetes mellitus. Diabetologia 29: 520A

24. Laborie C, Sai P, Feutren G, Debray-Sachs M, Quiniou-Debrie MC, Poussier P, Marliss EB, Assan R (1985) Time course of islet cell antibodies in diabetic and non-diabetic BB rats. Diabetes 34 : 904-910

25. Yale J-F, Grose M, Marliss EB (1985) Time course of the lymphopenia in BB rats. Relation to the onset of diabetes. Diabetes 34: 955-959

26. Reddy S, Bibby NJ, Fisher SL, Elliott RB (1986) Longitudinal study of first phase insulin release in the BB rat. Diabetologia 29: 802-807

Received: 14 August 1987

and in revised form: 23 February 1987

Dr. S. Reddy

Department of Pacdiatrics

Lniversity of Auckland School of Medicine

85 Park Road

Auckland 1

New Zealand 